JIOM Nepal. Volume 41 Number 3. December 2019, page 44-48.

\title{
Awareness Regarding Child Abuse among Mothers Attending a Paediatric Clinic of a Tertiary Level Hospital, Kathmandu
}

\author{
Tulashi Adhikari Mishra', Tilarupa Bhattarai ${ }^{2}$ \\ ${ }^{1}$ Department of Paediatric Nursing, Maharajgunj Nursing Campus, Institute of Medicine, Tribhuvan University, \\ Kathmandu, Nepal, 'Department of Psychiatric Nursing, Maharajgunj Nursing Campus, Institute of Medicine, \\ Tribhuvan University, Kathmandu, Nepal
}

\section{Corresponding author:}

Tulashi Adhikari Mishra

Department of Paediatric Nursing, Maharajgunj Nursing Campus, Institute of Medicine, Tribhuvan University, Kathmandu, Nepal

Email:tulsikadhikari@gmail.com

Submitted : September 25, 2019

Accepted : November 27, 2019

\begin{abstract}
Introduction

Child abuse constitutes all forms of physical as well as emotional maltreatment resulting in harm to the child's health and overall development. Parental awareness plays a significant role in the prevention of child abuse. The objective of this study was to find out the awareness of mothers regarding child abuse.
\end{abstract}

\section{Methods}

This descriptive cross sectional study was carried out among mothers attending a Pediatric Outpatient Department of Tribhuvan University Teaching Hospital Kathmandu, Nepal. A total of 162 mothers having their children of aged one to 16 years were selected as a sample using non-probability convenient sampling technique. Data was collected by face to face interview using semi-structured interview schedule.

\section{Results}

Findings of the study revealed that majority of mothers could state different types of abuse as physical abuse (72.8\%), psychological abuse (78.4\%), sexual abuse (71.6\%), but $53.1 \%$ of mothers were aware about neglect, $48.8 \%$ of mothers considered that relatives could abuse their child. In total, $49.1 \%$ of mothers had moderately adequate, $26.4 \%$ had inadequate and $23.9 \%$ had adequate level of awareness regarding child abuse. No significant association was noted between the level of awareness and mothers' age, ethnicity, religion and occupation. The level of awareness of mothers was significantly associated with nuclear family type $(p=0.03)$.

\section{Conclusion}

The mothers are aware of child abuse at moderate level. Conducting awareness programmes in community, regarding child abuse focusing on child neglect is recommended.

Keywords: Awareness, child abuse, knowledge, mother, parent

\section{INTRODUCTION}

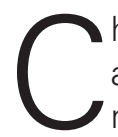

hild abuse constitutes all forms of physical and emotional ill treatment, sexual abuse, neglect or other exploitation, resulting in actual or potential harm to the child's health, survival and development. ${ }^{1}$ Child abuse is a common problem worldwide. Even in developed countries, two in five of the parents/guardians are in the practice of giving corporal punishments. ${ }^{2}$ The most common type of abuse is neglect $(64 \%$ of cases), followed by physical abuse (16\%), sexual abuse $(8.8 \%)$, emotional maltreatment $(6.6 \%)$, and other forms of abuse (4\%). ${ }^{3}$ In context of Nepal, approximately $3 \%$ children were beaten up hard. Young age of child, absence of father at home 
increased the risk. ${ }^{4}$ In the period of six months (January-June 2008), among total victims of rape, $64 \%$ were below 16 years of age. ${ }^{5}$ Children face abuses in their homes, schools and workplaces. In context of Nepal, mothers are primary caretaker of children at home. It has been revealed that $90 \%$ of mothers had inadequate knowledge and did not understand the meaning of child abuse and so failed to identify the signs and symptoms. ${ }^{6}$ If the mothers have adequate awareness about child abuse they can protect their children from abuse and identify it on time if has occurred. So, lots of negative consequences on children's mental and physical health can be prevented. The purpose of this study is to identify the awareness of the mothers regarding child abuse, and to measure the association between levels of knowledge of mothers with selected variables. The findings of this study may guide the nurses working with mothers to educate them about different aspects of child abuse.

\section{METHODS}

Descriptive cross sectional study design was used to assess the awareness of mothers regarding child abuse. It was conducted from May to June 2019 in Pediatric Out Patient Department (OPD) of Tribhuvan University Teaching Hospital (TUTH) of Kathmandu. Proposal was approved from Rector's Office, Centre for Research, Tribhuvan University, Kritipur. Ethical approval was obtained from Institutional Review Committee of Institute of Medicine, Tribhuvan University, Kathmandu, Nepal. Mothers attending OPD with their children of age group 1-16 years were the study population. Non-probability convenient sampling technique was used until the desired sample size of 162 was achieved. Data was collected in face to face interview by researchers and one research assistant with educational qualification of Bachelor Degree in Nursing, using pretested interview schedule translated in Nepali language developed by the researchers after reviewing related literature related to child abuse and getting feedbacks from experts. The tool consisted of three parts: part one including the questions related to socio-demographic characteristics of mothers (age, ethnicity, religion, family type, education, occupation), part two including the information related to number and sex of child in the family and part three including the questions related to mother's awareness related to child abuse (meaning of abuse and its different types, potential abuser, causes, consequences, preventive measures of child abuse). The mothers were interviewed separately after getting informed consent utilizing their waiting time at the corner of the waiting area.
Table 1. Awareness of mothers regarding concept of child abuse $(n=162)$

\begin{tabular}{|c|c|}
\hline Variables & $\begin{array}{c}\text { Responses } \\
\text { (\%) }\end{array}$ \\
\hline $\begin{array}{l}\text { Meaning of child abuse* } \\
\text { Harming child by doing any activity } \\
\text { Not providing needed care }\end{array}$ & $\begin{array}{c}137(84.6) \\
51(31.5)\end{array}$ \\
\hline $\begin{array}{l}\text { Relationship of child with abuser } \\
\text { might be * } \\
\text { Parents } \\
\text { Relatives } \\
\text { Teacher } \\
\text { Siblings } \\
\text { Neighbour } \\
\text { Stranger } \\
\text { Others } \\
\text { Don't know }\end{array}$ & $\begin{array}{c}68(42) \\
79(48.8) \\
76(46.9) \\
44(27.2) \\
115(71.0) \\
24(14.8) \\
4(2.5) \\
4(2.5)\end{array}$ \\
\hline $\begin{array}{l}\text { Types of abuse* } \\
\text { Physical } \\
\text { Psychological } \\
\text { Sexual abuse } \\
\text { Neglect } \\
\text { Don't know any type }\end{array}$ & $\begin{array}{c}118(72.8) \\
127(78.4) \\
116(71.6) \\
86(53.1) \\
18(11.1)\end{array}$ \\
\hline $\begin{array}{l}\text { Physical abuse is } \\
\text { Beating, kicking and burning \# } \\
\text { Scolding in front of friend } \\
\text { Threatening } \\
\text { Not providing education } \\
\text { Don't know }\end{array}$ & $\begin{array}{c}143(88.3) \\
1(0.6) \\
2(1.2) \\
7(4.3) \\
9(5.6)\end{array}$ \\
\hline $\begin{array}{l}\text { Psychological abuse is } \\
\text { Beating } \\
\text { Scolding, threatening and stopping } \\
\text { communication \# } \\
\text { Touching with bad intent } \\
\text { Providing drugs } \\
\text { Don't know }\end{array}$ & $\begin{array}{c}4(2.5) \\
139(85.8) \\
8(4.9) \\
5(3.1) \\
6(3.7)\end{array}$ \\
\hline $\begin{array}{l}\text { Sexual abuse is } \\
\text { Involving in hard physical work } \\
\text { lgnoring health needs } \\
\text { Touching different body parts and } \\
\text { involving in sexual act \# } \\
\text { Keeping at home without } \\
\text { guardian's supervision } \\
\text { Don't know }\end{array}$ & $\begin{array}{c}144(88.9) \\
2(1.2) \\
8(4.9)\end{array}$ \\
\hline $\begin{array}{l}\text { Negligence is } \\
\text { Using as child labour } \\
\text { Giving physical punishment } \\
\text { Involving in sexual act } \\
\text { Not providing needed care\# } \\
\text { Don't know }\end{array}$ & $\begin{array}{c}4(2.5) \\
5(3.1) \\
4(2.5) \\
142(87.7) \\
7(4.3)\end{array}$ \\
\hline
\end{tabular}

The data was analyzed by using SPSS Statistics version 16 with the help of descriptive statistics such as frequency, percentage, mean, standard 
Table 2. Mothers' awareness about various aspects of child abuse $(n=162)$

\begin{tabular}{lc}
\hline \multicolumn{1}{c}{ Aspect } & $\begin{array}{c}\text { Responses } \\
(\%)\end{array}$ \\
\hline Risk factors* & $125(72.2)$ \\
Lack of education in parents & $81(50)$ \\
Single parent & $119(73.5)$ \\
Substance abuse in parents & $116(71.6)$ \\
Poor economic status of family & \\
Inability to provide adequate time & $126(77.8)$ \\
to children & $96(59.3)$ \\
Presence of disability in child & \\
Possible consequences in future* & \\
Decreased cognitive and mental & $145(89.5)$ \\
development & $93(57.4)$ \\
Decreased physical development & $121(74.7)$ \\
Decreased self confidence & $101(62.3)$ \\
Involving in high risk behaviour & $78(48.1)$ \\
Disability & $3(1.8)$ \\
Others & \\
Mothers' role* & $120(74.1)$ \\
Participating in child's activity & $129(79.6)$ \\
Providing enough time to children & \\
Making child aware of good and & $137(84.6)$ \\
bad behaviour of others & \\
Noticing the changes in child's & $(66.7)$ \\
behaviour & \\
\hline & \\
\hline
\end{tabular}

${ }^{*}$ Multiple response

deviation and inferential statistics such as Chisquare tests with level of significance as 0.05 .

\section{RESULTS}

Among 162 mothers, majority (64.8\%) were from age group 21-30 years with mean age of 29.1 years. Nearly half (53.7\%) were Brahmin/ Chhetri and majority (86.4\%) were following Hinduism. More than half $(58 \%)$ of mothers were from joint family. Regarding education, $35.2 \%$ of mothers had studied upto higher secondary level and only $11.7 \%$ of mothers had achieved education of Bachelor level and above. Concerning occupation, nearly two third $(64.8 \%)$ of mothers were homemakers, one fifth (19.1\%) were job holder and $2.5 \%$ were foreign employee.

Table 1 shows that $84.6 \%$ of mothers considered child abuse as harming child by doing any activities. The most commonly considered potential abuser were neighbour (71\%) followed by relatives $(48.8 \%)$ teachers $(46.9 \%)$, parents $(42 \%)$, sibling $(27.2 \%)$ and strangers (14.8\%), Majority (78.4\%) of mothers were aware of psychological abuse, $53.1 \%$ of mothers could name neglect as type of abuse. Majority of mothers were aware of meaning of physical abuse (88.3\%), psychological
Table 3. Mothers' level of awareness on child abuse $(n=162)$

\begin{tabular}{lc}
\hline \multicolumn{1}{c}{ Level of awareness } & Frequency (\%) \\
\hline Inadequate $(0-50) \%$ & $43(26.4)$ \\
Moderately adequate (51-75)\% & $80(49.1)$ \\
Adequate $(>75 \%)$ & $39(23.9)$
\end{tabular}

*Maximum obtainable score was 38, mean score was $23.33(61.40 \%)$

abuse $(85.8 \%)$, and sexual abuse $88.9 \%$ and neglect $(87.7 \%)$.

Table 2 depicts the awareness on the risks factors associated with child abuse, where the most commonly considered risks factors were inability to provide adequate time to children (77.8\%), substance abuse by parents $(73.5 \%)$, lack of education in parents $(72.2 \%)$ and presence of disability in child (59.3\%).

Table 2 also indicates that decreased cognitive and mental development was the most commonly considered consequence of child abuse by $89.5 \%$ of mothers. Table 2 also shows the awareness of mothers on their role to prevent child abuse, where $84.6 \%$ responded as making their child aware of good and bad behaviours of others.

Table 3 indicates that $26.4 \%$ of mothers had inadequate, $49.1 \%$ had moderately adequate and $23.9 \%$ had adequate level of awareness regarding child abuse.

Table 4 shows that the level of awareness of mothers was not statistically associated with age $(p=0.48)$, ethnicity $(p=0.15)$, religion $(p=0.09)$ and occupation $(p=0.78)$. Whereas, level of awareness was statistically associated with family type ( $p=$ 0.03).

Regarding governmental activities against child abuse, more than half of the mothers (59.3\%) believed that no single activity was carried out by the government against it, while $16.7 \%$ were ignorant about the asked question. Nearly a quarter (24.1\%) of mothers agreed that there are some activities conducted by the government against child abuse but however they were ignorant about the types of activities. Most of the mothers (90.1\%) wanted to suggest the government to carry out awareness programmes about child abuse, while only few (3\%) wanted to suggest other methods like provision of CCTV at school and including the content of child abuse in curriculum.

\section{DISCUSSION}

In the present study, majority (84.6\%) of mothers considered child abuse as commission of any activity that harms the child, but only $31.4 \%$ of them thought that omission of needed care is 
Table 4. Association of mothers' level awareness on child abuse with selected variables $(n=162)$

\begin{tabular}{|c|c|c|c|c|}
\hline \multirow{2}{*}{ Selected Variables } & \multicolumn{3}{|c|}{ Level of awareness } & \multirow{2}{*}{ P-value } \\
\hline & Inadequate (\%) & Moderately adequate (\%) & Adequate (\%) & \\
\hline $\begin{array}{l}\text { Age } \\
<30 \text { years } \\
\geq 30 \text { Years }\end{array}$ & $\begin{array}{l}23(14.2) \\
20(12.3)\end{array}$ & $\begin{array}{l}48(29.6) \\
32(19.8)\end{array}$ & $\begin{array}{l}19(11.7) \\
20(12.3)\end{array}$ & 0.48 \\
\hline $\begin{array}{l}\text { Ethnicity } \\
\text { Brahmin Chhetri } \\
\text { Other }\end{array}$ & $\begin{array}{l}20(12.3) \\
23(14.2)\end{array}$ & $\begin{array}{l}41(25.3) \\
39(24.1)\end{array}$ & $\begin{array}{c}26(16.0) \\
13(8.0)\end{array}$ & 0.15 \\
\hline $\begin{array}{l}\text { Family Type } \\
\text { Nuclear } \\
\text { Joint }\end{array}$ & $\begin{array}{c}11(6.8) \\
32(19.8)\end{array}$ & $\begin{array}{l}39(24.1) \\
41(25.3)\end{array}$ & $\begin{array}{l}189(11.1) \\
21(13.0)\end{array}$ & 0.03 \\
\hline $\begin{array}{l}\text { Religion } \\
\text { Hindus } \\
\text { Non Hindus }\end{array}$ & $\begin{array}{c}40(24.7) \\
3(1.3)\end{array}$ & $\begin{array}{c}70(43.2) \\
10(6.2)\end{array}$ & $\begin{array}{c}30(18.5) \\
9(5.6)\end{array}$ & 0.09 \\
\hline $\begin{array}{l}\text { Occupation } \\
\text { Home Maker } \\
\text { Working outside }\end{array}$ & $\begin{array}{l}26(16.0) \\
17(10.5)\end{array}$ & $\begin{array}{l}53(32.7) \\
27(16.7)\end{array}$ & $\begin{array}{c}26(16.0) \\
13(8.0)\end{array}$ & 0.78 \\
\hline
\end{tabular}

also a child abuse. More than two third of mothers perceived that neighbour could be the possible culprit for abuse of their child, followed by relatives $(48.8 \%)$ and teachers $(46.9 \%)$. More than two third of mothers were aware of types of abuse as physical abuse $(72.8 \%)$, psychological abuse $(78.4 \%)$ and sexual abuse $(71.6 \%)$. This findings is contradicted by a study conducted in a community of New Delhi which revealed that $90 \%$ of mothers had inadequate knowledge regarding sexual abuse. ${ }^{7}$ Similar contradictory findings in India was noted by a study of Rajendra ${ }^{8}$ indicating that $43 \%$ of mothers could correctly state the different types of child abuse. In present study, $53.1 \%$ of the mothers were aware of neglect as a type of abuse.

However, , in a study from Western Saudi Arabia by Helmyl and Aljiuad and team ${ }^{9}, 72.3 \%$ of mothers perceived neglect as important problem. In this study, majority of mothers (77.8\%) were aware that inability to provide adequate time to the children can increase their child's vulnerability for being abused, whereas only half of them (50\%) believed that rearing the child by single parent is also a risk factor for child abuse. Most of the mothers (89.5\%) agreed that decreased cognitive and mental development can be the consequence of child abuse in abused child. Similarly major proportion $(84.6 \%)$ of mothers agreed making child aware of good and bad behaviour of others can be the important role of mother in protecting child from abuse while only (66.7\%) believed that noticing the changes in the child behaviour is also an effective role of mother in protecting their child from abuse. Most of the mothers (90.1\%) wanted to suggest the government to carry out awareness programme regarding child abuse as an act to root out the prevailing child abuse problem in the society. Similarly, (87\%) agreed to punish the abuser as an effective programme, $72.2 \%$ suggested rehabilitating the abused child.

In overall, $23.9 \%$ had adequate level of awareness; a quarter $(26.4 \%)$ had inadequate and remaining $49.1 \%$ had moderate level of awareness regarding child abuse.This is somewhat similar to the finding of study by Thangavelu ${ }^{10}$ in India where $15 \%$ samples had inadequate awareness, $85 \%$ sample had moderately adequate awareness and another similar findings was noted in study from Mangalore India ${ }^{11}$, where majority of mothers had average knowledge, likewise, other study from Nepal12 showed that $77.8 \%$ mothers had average level of awareness about child abuse.However, in contrast, a study by Jacob ${ }^{13}$ conducted among 100 mothers in selected residential areas of Delhi revealed that only $3 \%$ of mothers had poor level of knowledge, $37 \%$ of them had average awareness. Another contradictory finding was noted by Gurung and Bhattarai ${ }^{14}$ in Nepal where $50.53 \%$ of parent had good knowledge and $48.4 \%$ had average knowledge.

In present study, awareness of mothers was not found to be influenced by any of socio-demographic variables except family type $(p=0.03)$. Findings from other studies 8,15,16 had also identified no significant association between level of awareness 
and socio-demographic variables. Finding from Rajendra ${ }^{8}$ and Thapa and Pun ${ }^{12}$ have supported the finding of present study about association of level of knowledge with mother's family type. Mothers from nuclear family were found to have greater awareness than others. The reason for better knowledge among mothers of nuclear family might be because they might had migrated from rural areas to city area for job and education purpose leaving their joint family at their native place. They might be autonomous and exposed to different sources of information during mobility.

\section{CONCLUSION}

The mothers are aware of physical, psychological and sexual abuse but few are aware about neglect. Nearly half of mothers think that relatives can be the potential abuser. Most of the mothers are aware of meaning of sexual abuse. Inability to provide adequate time to the children was the most commonly considered risk factor for child abuse. Level of awareness regarding child abuse among the mothers of a child is average. The mothers from nuclear family background tend to have greater level of awareness than the mothers from joint family.

\section{ACKNOWLEDGEMENT}

The researchers are grateful towards The Rector's Office, Centre for Research, Tribhuvan University, Kirtipur for providing grant to conduct this study and Institutional Review Committee of TU, Institute of Medicine for providing ethical approval of this study and participant mothers for their cooperation during this study.

\section{CONFLICT OF INTEREST}

None declared.

\section{REFERENCES}

1. World Health Organization. World Report on Violence and Health. Geneva: World Health Organization; 2002. WHO childabuse $\% 20$ def\%20 Camp.pdf.

2. Radford L, CorralS, Bradley C, Fisher H, Bassett C, Howat N,Collishaw S. Child abuse and neglect in the UK today. London: NSPCC; 2011.

3. Nettina SM. Lippincott manual of nursing practice, 9th ed. India: Wolters Kluwer Health/ Lippincott Williams \& Wilkins; 2012.

4. KandelP, KunwarR, Karki S, KandelD, LamichhaneP. Child maltreatment in Nepal: prevalence and associated factors. Public Health 2017; 151: 106113. https://www.sciencedirect.com/science/ article/pii/S0033350617302238?via\%3Dihub.

5. Child Workers in Nepal Concerned Centre. Child abuse in Nepal Increasing. https://www.cwin.org. $\mathrm{np} /$ index.php/media-centre/press-release/36child-sexual-abuse-increasing.html

6. Bharathi M, Ramu K. A descriptive study to assess the knowledge on child abuse among mothers residing at selected rural areas, in Bangalore. JOSR-JNHS .2018; 7(5): 8-10.

7. Kaushik A, Daniel S. Knowledge and attitude of mothers regarding prevention of child sexual abuse. Int J. Nurs. a Midwif. 2017; 4(4):42-48

8. Rajendra K. Knowledge of mothers regarding child abuse in rural areas. JOSR-JHSS 2016;21(7):32-3

9. Helmyl FF, Aljiuad RM, Alsufyani MH, Alsufyani SA, Alkhadi AS. Mother's awareness about different types of child abuse in Taif region (Western KSA). EC Paediatrics 2017; 5(4): 89-96

10. Thangavelu SN. Assess the level of knowledge regarding child abuse among the mothers in selected areas at Latur. J Child Adolesc Behav. 2016; 4(271) e10002171

11. Abraha JF, Hemavathy $V$. A study on effectiveness of planned teaching programme on knowledge and attitude regarding child abuse among the mothers of primary school children in a selected rural school in Mangalore taluk. IJIRSET. 2015; 4(2):431-436

12. Thapa T, Pun KM, Raut KB, Silwal K, Chudhary RK. Awareness on girl child abuse among mothers of a selected community. JNMA 2018; 56(213):86670

13. Jacob J, Kumar K. A study to assess the knowledge regarding child abuse among mother's in selected residential areas of Delhi. IOSR-JNHS 2018; 7(6): 29-31.

14. Gurung L, Bahattarai S. Knowledge of child abuse among parents of under 5 years children in Kathmandu, Nepal. JMMIHS. 2015; 1(4):9-13

15. Devi MA, Yadav R. Knowledge regarding child abuse among parents. Int $\mathrm{J}$ of Advances in Nur Management. 2016;4(3):191-3.

16. Pappachan B, Jipsa $P$, Pinto J, Kurian NA, Rodrigues VR. Knowledge of mothers regarding prevention of child abuse. Innovational Journal of Nursing and Healthcare 2017; 3(1):7-10 